\title{
Effect of Internal Recycle Ratio on Nitrogen Removal Efficiency in a Three-stage ANAMMOX Process for Treating Reject Water
}

\author{
Daehee Choi ${ }^{1 \oplus} \cdot$ Wonsang Yun ${ }^{2 \odot} \cdot{\text { Dongjin } \mathrm{Ju}^{2 \odot} \cdot \text { Jinyoung Jung }}^{1,+\odot}$ \\ ${ }^{1}$ Department of Environmental Engineering, Yeungnam University \\ ${ }^{2}$ Samjin Precision Co., Ltd.
}

(Received April 2, 2020; Revised May 4, 2020; Accepted May 12, 2020)

Objectives: In order to improve the stability of the ANAMMOX process, a three-stage ANAMMOX process combined with denitritation/nitritation process was operated, and effect of internal recycle ratio on the nitrogen removal efficiency was investigated.

Methods: For the treatment of supernatant from anaerobic digester, a three-stage ANAMMOX process which combined as anoxic/oxic reactor and subsequent ANAMMOX reactor was installed. The reactor was designed with a working volume of $2.5 \mathrm{~m}^{3}$. The internal recycle ratio was considered as the main operating parameter, and the performance of nitrogen removal in the ANAMMOX process was evaluated.

Results and Discussion: As the internal recycle ratio was increased from 0 to $1.5 \mathrm{Q}$, reduction of the nitrogen load increased to $23.5 \pm 3.8 \%$, and the nitrogen load reduced by internal recycle was $0.22 \pm 0.04 \mathrm{kgN} / \mathrm{m}^{3} / \mathrm{d}$. Since the ratio of $\mathrm{NO}_{2}-\mathrm{N} / \mathrm{NH}_{3}-\mathrm{N}$ introduced in the ANAMMOX process is very important, considering this together, the most suitable internal recycle ratio was determined to be $1.5 \mathrm{Q}$. As a result of introducing the effluent from the $\mathrm{A} / \mathrm{O}$ process into the ANAMMOX process, the nitrogen removal rate could be stably maintained at $1.27 \mathrm{~kg} / \mathrm{m}^{3} / \mathrm{d}$.

Conclusions: In the ANAMMOX process in conjunction with the $\mathrm{A} / \mathrm{O}$ process including internal recycle, the $\mathrm{A} / \mathrm{O}$ process represented an effect of reducing the influent nitrogen load and nitrite concentration, and the ANAMMOX process was able to effectively remove residual nitrogen.

Key Words: Three-stage ANAMMOX Process, Anaerobic Ammonium Oxidation, Partial Nitritation, Internal Recycle Ratio, Nitrogen Removal 


\title{
연구논문
}

\section{반류수 처리를 위한 3단 아나목스 공정에서 내부 반송률이 질소 제거 효율에 미치는 영향}

\author{
최대희 $^{1 \oplus} \cdot$ 윤원상 $^{2 \oplus} \cdot$ 주동진 $^{2 \oplus} \cdot$ 정진영 $^{1,+\odot ~}$ \\ ${ }^{1}$ 영남대학교 환경공학과 \\ ${ }^{2}$ (주)삼진정밀
}

목적 : 본 연구에서는 아나목스 공정의 안정성을 향상시키기 위하여 아탈질/아질산 공정과 결합된 3단 아나목스 공 정에 대한 연구를 수행하였으며, 질소 제거 효율 및 제거속도에 대한 내부 반송률의 영향을 조사하였다.

방법: 혐기성 소화 탈리액 내 고농도의 질소를 처리하기 위하여 $\mathrm{A} / \mathrm{O}$ 공정과 연계된 3단 아나목스 공정이 적용되 었다. 반응조의 유효운전부피는 $2.5 \mathrm{~m}^{3}$ 으로 제작되었다. 주요 운전 인자로서 내부 반송률이 고려되었으며, 이에 따 른 아나목스 공정에의 질소 제거 성능을 평가하였다.

결과 및 토의 : 내부 반송률을 0 에서 $1.5 \mathrm{Q}$ 로 증가시킴에 따라 질소 부하 저감 효과는 $23.5 \pm 3.8 \%$ 까지 증가하였고, 내 부 반송에 의해 저감된 질소 부하는 $0.22 \pm 0.04 \mathrm{kgN} / \mathrm{m}^{3} / \mathrm{d}$ 이었다. 아나목스 공정에서는 유입되는 $\mathrm{NO}_{2}-\mathrm{N} / \mathrm{NH}_{3}-\mathrm{N}$ 의 비 가 매우 중요하기 때문에 이를 함께 고려하여, 가장 적합한 내부 반송률은 $1.5 \mathrm{Q}$ 로 결정되었다. $\mathrm{A} / \mathrm{O}$ 공정의 유출수 를 아나목스 공정으로 유입시킨 결과, 질소 제거 속도는 $1.27 \mathrm{~kg} / \mathrm{m}^{3} / \mathrm{d}$ 에서 안정적으로 유지될 수 있었다.

결론 : 내부 반송을 포함한 $\mathrm{A} / \mathrm{O}$ 공정과 연계한 아나목스 공정에서 $\mathrm{A} / \mathrm{O}$ 공정은 유입 질소 부하 및 아질산염 농도 저 감 효과를 나타내었고, 아나목스 공정에서는 잔류 질소를 효과적으로 제거할 수 있었다.

주제어: 3 단 공정, 혐기성 암모늄 산화, 부분 아질산화, 내부 반송률, 질소 제거

\section{1. 서 론}

국내 하·폐수 처리장에서는 2003년부터 전국적으로 총 질소에 대한 배출허용 기준이 적용되어 왔고, 현재 질소의 배출허용기준은 동절기를 포함하여 $\mathrm{TN} 20 \mathrm{mg} / \mathrm{L}$ 로 규정되 어 있다. ${ }^{1)}$ 최근에는 4 대강 녹조 문제를 해결하기 위하여 질 소 규제에 대한 필요성이 점차 부각되고 있으며'2), 선진국 수준을 고려할 때 국내 방류 질소 규제 수준은 점차 강화될 것으로 판단된다. ${ }^{3,4)}$

하수처리장 처리수 내 질소 농도에 악영향을 미치는 주요 요인으로 혐기성 소화 유출수가 고려되고 있다. 해당 폐수 는 유입 유량 대비 $2 \%$ 인 반면, 유입 질소부하 대비 $15-30 \%$ 인 특성을 지니고 있으며5), 대부분 별도로 처리되지 않고 유량 조정조나 침사지로 반송시켜 하·폐수처리장의 질소부 하를 가중시키는 요인으로 작용하고 있다.,7)

최근 고농도 질소 함유 폐수를 처리하기 위하여 혐기성 암모 늄 산화 공정(ANaerobic AMMonium OXidation, ANAMMOX) 에 대한 연구가 활발히 수행되어 왔다. ${ }^{8,9)}$ 아나목스 미생물은
혐기성 조건에서 아질산염을 전자 수용체로 암모늄을 산화시 킬 수 있는 특이한 질소 제거 경로를 지니고 있다. ${ }^{10)}$ 이로 인하여 질산화/탈질화로 구성된 기존 질소 제거 공정 대비 약 $50 \%$ 이상의 폭기 에너지를 절감할 수 있는 비용-효율적인 공정으로 고려되고 있다. ${ }^{11)}$

아나목스 공정은 2002년도에 첫번째 full-scale 공정이 Rotterdam에서 적용되었으며 ${ }^{12)}$, 이때 부분 아질산화와 연계된 2단 질소 제거 공정이 적용되었다. 하지만 2단 질소 제거 공정 의 불안정성은 다양한 연구자들에 의해 보고되었고 ${ }^{13-16)}$, 이후 다양한 현장 경험과 함께 부분 아질산화와 ANAMMOX 공정 이 단일 반응조에서 구현되는 1단 질소 제거 공정이 주로 적용 되어져 왔다. ${ }^{17-19)}$ Full-scale ANAMMOX 공정 중 $90 \%$ 이상이 1 단 질소 제거 공정으로 적용되었다고 보고되었다. ${ }^{20)}$

2단 질소 제거 공정에서 1단 질소 제거 공정으로 그 트렌 드가 변화된 주요 원인 중 하나로 유입 질소 부하 변동이 고려되고 있다. ${ }^{21)}$ 실제 혐기성 소화 유출수 성상은(질소, 유 기물) 하수처리장 잉여 슬러지 처리 정책, 혐기성 소화조 운 전 효율 등에 따라 변동폭이 매우 심한 것으로 보고되고 있 


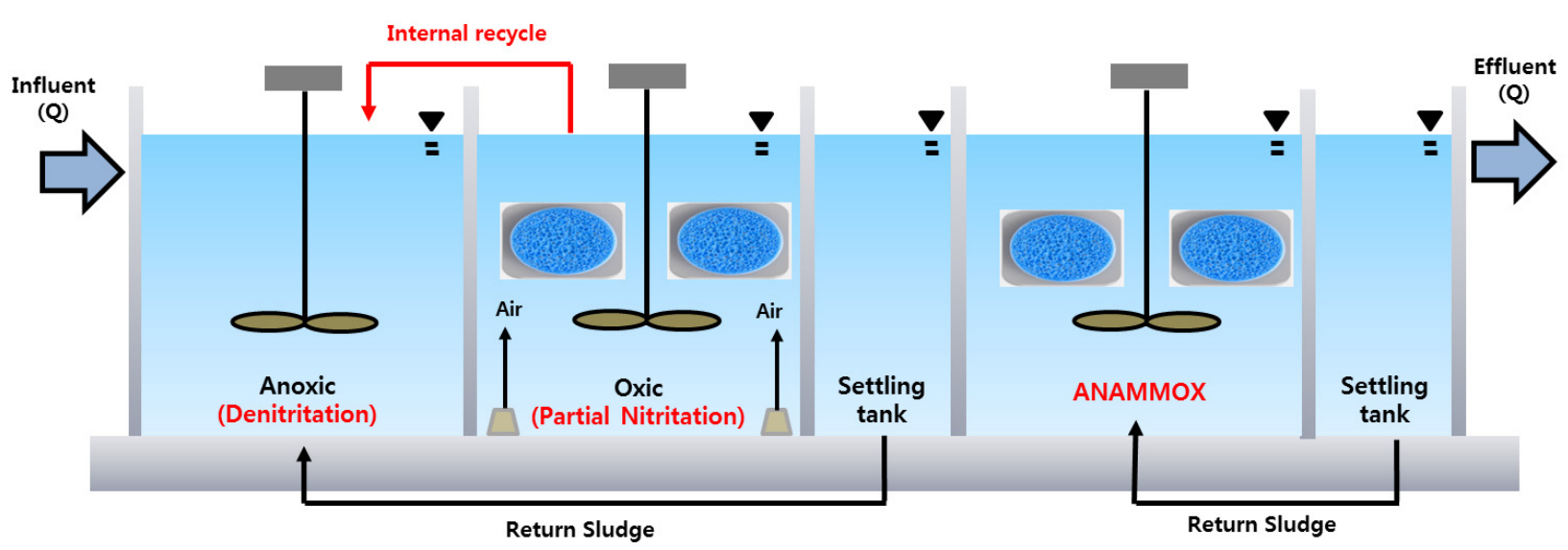

Fig. 1. Schematic diagram of three-stage ANAMMOX process.

다. ${ }^{22)}$ 이는 아나목스 미생물에 강한 독성 영향을 나타나는 아질산염의 농도 조절을 어렵게 만들어 전반적인 공정의 안 정성 악화를 야기한다. ${ }^{23)}$

고농도 질소 함유 폐수의 성상은 혐기성 소화조 운영 효 율 및 잉여 슬러지 처리 정책에 따라 변동되고, 이는 아나목 스 미생물 활성에 저해를 미치는 유기물 및 질소 농도 변화 를 초래한다. 또한 하수처리장 에너지 자립화에 대한 관심 이 증가되고 있는 시점에서 혐기성 소화조의 활용폭은 점차 증가될 전망이며, 이는 혐기성 소화 유출수 내 질소 농도의 급격한 증가를 야기하게 되고, 결국 부분 아질산화조에서 생성되는 높은 아질산염 농도에 의해 아나목스 공정의 안정 성은 악화될 가능성이 매우 높다.

본 연구에서는 2 단 질소 제거 공정에서의 문제점으로 대 두되고 있는 공정 안정성 문제를 해결하기 위하여 아탈질/ 아질산/아나목스로 구성된 3단 질소 제거 시스템을 개발하 였다. 아탈질/아질산 공정에서는 유기물 및 질소 충격 부하 를 저감시킴으로써 아나목스 공정의 안정성 향상에 기여할 수 있을 것으로 기대되며, 주요 변수 중 하나로 내부 반송률 에 따른 질소 부하 저감률이 고려되었다. 3 단 질소 제거 공 정은 경산 폐수처리장에 설치되어 약 300 일 동안 운전되었 으며, 적용 변수에 따른 질소 제거능이 평가되었다.

\section{2. 실험방법}

\subsection{A/O+ANAMMOX 공정 구성}

경산 하수처리장에서 적용된 3 단 질소 제거 공정의 개념도 는 Fig. 1 에 나타내었다. 아탈질/아질산화 공정은 $\mathrm{A} / \mathrm{O}$ 시스템 을 기반으로 구현되었으며, 각 반응조의 working volume은 $0.5 \mathrm{~m}^{3}, 1 \mathrm{~m}^{3}$ 이었다. 이후 침전조에서 고액 분리된 슬러지 는 외부 반송 시스템을 통하여 무산소조로 이송되었고, 호 기조에서 아질산염으로 산화된 질소 성분은 탈질 반응을 유 도하기 위하여 무산소조로 내부 반송되었다. 호기조에서 용 존 산소(dissolved oxygen, DO)는 Hach DO sensor를 이용하
여 $0.5 \mathrm{mg} \mathrm{O} / 2$ 미만으로 조절되었고, 별도의 $\mathrm{pH}$ 조절 시스 템은 적용되지 않았다. 아탈질/아질산 공정에서 운전 효율 을 평가하는 주요 기준으로 내부 반송률 $(0,1.5 \mathrm{Q}, 3.0 \mathrm{Q})$ 에 따른 아나목스 공정 적용을 위한 유출수 $\mathrm{NO}_{2} / \mathrm{NH}_{4}$ 기질비와 질소 부하 저감률이 고려되었다. 여기서 질소 부하 저감률 은 다음과 같은 식을 통하여 산정되었다.

\section{질소 부하 저감률(\%)}

$$
=(\text { Inf. TN }- \text { Eff. TN }) / \text { Inf. TN } \times 100
$$

아나목스 공정은 working volume $1 \mathrm{~m}^{3}$ 으로 제작되었다. 운전 초기에는 유입 질소 부하를 낮게 유지하여 운전하였으 나, 아나목스 미생물의 순응 정도에 따라 유입 질소 부하는 점차 증가되었고, 공정 안정화 이후 전체 공정의 수리학적 체류시간(Hydraulic retention time, HRT)는 $16 \mathrm{~h}$ 으로 조절되 었다.

\section{2. 식종 미생물}

아질산화/아탈질 공정에서 사용된 식종 미생물은 경산 하 수처리장에서 운영되고 있는 $\mathrm{A}^{2} \mathrm{O}$ 시스템에서 채취되었다. 운전 초기 반응조 내 MLSS (mixed liquid suspended solid) 농도는 $4,500 \mathrm{mg} / \mathrm{L}$ 이었다. 아나목스 미생물은 운영 중인 미 생물 대량 배양 시스템으로부터 채취되었으며, 채취 당시 배양조에서의 질소 제거 속도는 $0.65 \mathrm{~kg} / \mathrm{m}^{3} / \mathrm{d}$ 을 나타내었다. 아나목스 공정에서의 미생물 농도는 $4,180 \pm 518 \mathrm{mg} / \mathrm{L}$ 로 유 지되었다.

\section{3. 유입수 성상}

경산 하수처리장에서 발생하는 실제 혐기성 소화 탈리액이 유입수로 사용되었다. 유입수의 주요 성상은 다음과 같다; $\mathrm{NH}_{4}{ }^{+}-\mathrm{N} 594.5 \pm 93 \mathrm{mg} \mathrm{N} / \mathrm{L}, \mathrm{NO}_{2}{ }^{-}-\mathrm{N} 0.1 \pm 0.1 \mathrm{mg} \mathrm{N} / \mathrm{L}, \mathrm{NO}_{3}{ }^{-}{ }^{-} \mathrm{N}$ $0.2 \pm 0.1 \mathrm{mg} \mathrm{N} / \mathrm{L}, \quad \mathrm{COD} 246.5 \pm 44.9 \mathrm{mg} \mathrm{O} \mathrm{O}_{2} / \mathrm{L}$, Alkalinity $2251 \pm 210.8 \mathrm{mg} \mathrm{CaCO}_{3} / \mathrm{L}, \mathrm{pH} 7.8 \pm 0.1$. 유입수 $\mathrm{C} / \mathrm{N}$ 는 운전 기 


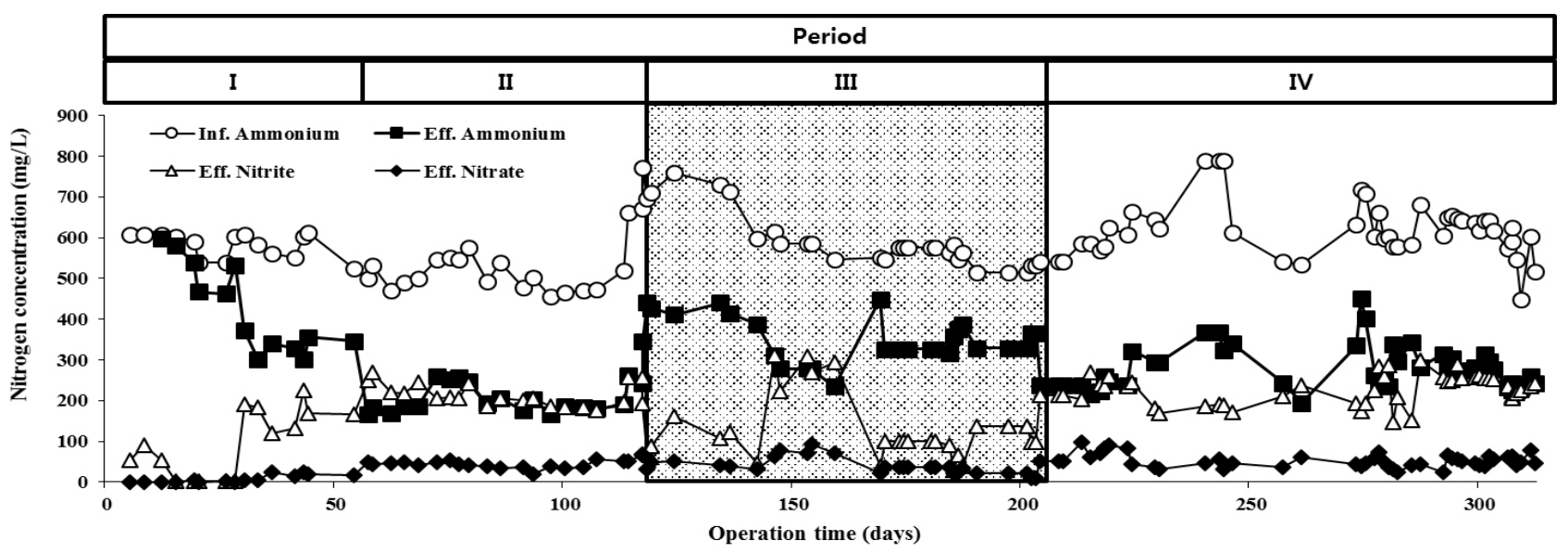

Fig. 2. Nitrogen removal performance in denitritation/nitritation reactor over operation time.

간 동안 $0.4 \pm 0.3$ 으로 유지되었다.

\section{4. 분석 방법}

모든 시료는 각 반응기의 유입수와 유출수를 채취하여 $0.45 \mu \mathrm{m}$ 의 공극을 가진 cellulose acetate 재질의 membrane filter를 이용하여 여과한 후 대상물질을 분석하였다. $\mathrm{NO}_{2}{ }^{-}-\mathrm{N}$, alkalinity, chemical oxygen demand (COD)는 Standard Methods (APHA, 2005)에 따라 분석을 실시하였다. 그리고 $\mathrm{NO}_{3}{ }^{-}-\mathrm{N}$ 은 이온크로마토그래피(ICS2100, DIONEX)를, $\mathrm{NH}_{4}{ }^{+}-\mathrm{N}$ 은 질소 분석기(2200 Kjeltec Auto Distillation, FOSS TECATORS) 를 이용하여 분석을 진행하였다. $\mathrm{pH}$ 와 temperature $\left({ }^{\circ} \mathrm{C}\right)$ 는 Horiba $\mathrm{pH}$ meter F-51을 이용하여 측정하였고, biochemical oxygen demand (BOD), suspended solid (SS)는 수질오염공 정시험방법에 따라 분석을 실시하였다. ${ }^{24)}$

\section{3. 결과 및 고찰}

\section{1. 아탈질/아질산 공정 성능 평가}

운전 기간은 시운전 기간인 period I 구간과, 공정 안정화 구간인 period II과 period IV구간으로 분할되었다. period III 구간은 유입수 확보 문제 및 반응기의 유지 및 보수 기 간으로 운전효율이 감소한 구간이었다. 아탈질/아질산 공정 은 312일 동안 운전되었고, 대표적인 운전 성능은 Fig. 2에 나타내었다.

슬러지 식종 이후 운전 26일까지 유입 암모늄의 산화 효 율은 최대 $14.3 \%$ 를 나타내었고, $\mathrm{A} / \mathrm{O}$ 유출 아질산염은 2.2 $\mathrm{mg} / \mathrm{L}$ 로 매우 낮게 나타났다. 하지만 이후 암모늄 산화효율 은 운전 43 일 만에 $50.2 \%$ 를 달성하였고 $\mathrm{A} / \mathrm{O}$ 유출 아질산염 농도 또한 $224 \mathrm{mg} / \mathrm{L}$ 까지 증가하는 것으로 나타났다. 상기 언급된 조건에서 유입 질소 부하는 $1.0 \pm 0.2 \mathrm{~kg} / \mathrm{m}^{3} / \mathrm{d}$ 로 운전 되었다. 이처럼 저농도 질소 함유 폐수에 순응한 미생물은 고농도 질소 함유 폐수에 순응하기 위하여 약 28 일이 소요
되는 것으로 나타났다.

Period II 구간에서는 내부 반송은 작동되지 않았고 적정 슬러지 농도 유지를 위한 외부 반송 시스템만이 가동되었 다. 해당 기간 동안 반응조는 아나목스 반응과의 연계를 위 하여 $\mathrm{A} / \mathrm{O}$ 유출수 내 $\mathrm{NO}_{2} / \mathrm{NH}_{4}$ 가 약 1 이 되도록 운전되었다. 목표 $\mathrm{A} / \mathrm{O}$ 유출 성상은 운전 57일부터 달성되었으며, 이때 유입 암모늄의 산화 효율은 $64.8 \pm 4.2 \%$ 이었고, $\mathrm{A} / \mathrm{O}$ 유출수 내 아질산염 농도는 $229.1 \pm 21.8 \mathrm{mg} / \mathrm{L}$ 이었다. 이 구간에서 $\mathrm{A} / \mathrm{O}$ 유출수 내 $\mathrm{NO}_{2} / \mathrm{NH}_{4}$ 는 $1.1 \pm 0.2$ 으로 유지되었다. 하지만 내부 반송 시스템이 없음에도 불구하고 질소 부하 저감률은 $7.1 \pm 0.6 \%$ 를 나타내었다. 일반적으로 아탈질/아질산 공정에 서의 질소 제거 매카니즘은 아질산화된 질소 성분이 아탈질 공정으로 내부 반송될 때 구현될 수 있다. 하지만 period I 과 period II 구간에서는 유입 질소중의 일부는 아탈질 공정 이 아닌 아질산 공정에는 제거되는 것으로 나타났다. 해당 기간 동안 유입 $\mathrm{COD}$ 농도는 $232 \pm 25 \mathrm{mg} \mathrm{O} / \mathrm{L}$ 이었는데, 내 부 반송 시스템이 적용되지 않은 구간에서 아탈질 공정에서 의 질소 제거는 거의 나타나지 않았다. 하지만 잔류하는 $\mathrm{COD}$ 는 호기성 반응조로 유입되었고, 이는 아질산과 함께 아탈질이 단일 반응시스템에 동시에 구현되는 현상을 야기 하게 되었다. 낮은 DO 농도가 유지되는 반응조에서 탈질화 또는 아탈질화는 다수 연구자들에 의해 보고 되어 왔다. ${ }^{25,26)}$ 본 연구 시스템에서 $\mathrm{DO}$ 농도는 $0.5 \mathrm{mg} \mathrm{O} \mathrm{O}_{2} / \mathrm{L}$ 로 조절되었고, 이로 인하여 호기성 반응조로 운전되었음에도 불구하고 일 부의 질소는 아탈질화되는 것으로 조사되었다.

이후 period III에서는 산기 장치 문제와 함께 유입수의 원 활한 공급이 이루어지지 않아 정상적인 질소 전환 성능이 확보되지 못하였다. 운전 117 일 시점부터 호기성 미생물인 $\mathrm{AOB}$ (ammonia oxidizing bacteria)의 활성도가 급격히 저 해되었고, 반응조 내 $\mathrm{pH}$ 가 8.2 까지 급격히 증가하는 것으 로 나타났다. 계산된 반응조 내 FA (free ammonia) 농도는 $51.7 \pm 11.9 \mathrm{mg} \mathrm{NH} / \mathrm{L}$ 이었는데 ${ }^{27)}$, 고농도 $\mathrm{FA}$ 는 산화된 아질산 염을 질산염으로 산화시키는 NOB (nitrite oxidizing bacteria) 
Table 1. The performance of denitritation/nitritation system according to the internal recycle ratio.

\begin{tabular}{cccc} 
& \multicolumn{3}{c}{ Internal recycle ratio } \\
\cline { 2 - 4 } Nitrogen load reduction rate (\%) & $0 \mathrm{Q}$ & $1.5 \mathrm{Q}$ & $3 \mathrm{Q}$ \\
$1^{\text {st, } *}$ Influent $\mathrm{NH}_{4}{ }^{-}-\mathrm{N}$ concentration $(\mathrm{mg} / \mathrm{L})$ & $7.1 \pm 0.58$ & $15.2 \pm 1.74$ & $23.5 \pm 3.85$ \\
$2^{\text {nd, }, * *}$ Effluent $\mathrm{NH}_{4}{ }^{+}-\mathrm{N}$ concentration $(\mathrm{mg} / \mathrm{L})$ & $598.9 \pm 62.08$ & $530.2 \pm 90.68$ & $632.8 \pm 10.4$ \\
$2^{\text {nd }}$ Effluent $\mathrm{NO}_{2}{ }^{-}-\mathrm{N}$ concentration $(\mathrm{mg} / \mathrm{L})$ & $211.3 \pm 38.58$ & $198.8 \pm 27.81$ & $329.9 \pm 33.03$ \\
Substrate ratio $\left(\mathrm{NO}_{2}-\mathrm{N}: \mathrm{NH}_{4}{ }^{+}-\mathrm{N}\right)$ & $229.1 \pm 21.76$ & $202.8 \pm 26.79$ & $183.2 \pm 8.10$ \\
\hline
\end{tabular}

$* 1^{\text {st }}$. Anoxic reactor

$* * 2^{\text {nd. }}$. Oxic for nitritation reactor

의 활성 저해에 효과적인 반면 ${ }^{28)}, \mathrm{AOB}$ 에게도 강한 독성 영 향을 야기하는 물질로 알려져 있다. $10 \mathrm{mg} \mathrm{NH} / \mathrm{L}$ 의 $\mathrm{FA}$ 농도 에서 $\mathrm{AOB}$ 의 활성은 저해된다고 보고되었다. ${ }^{29)}$ 이처럼 산기 시스템 및 원활하지 못한 유입수 공급은 반응조 내 $\mathrm{pH}$ 의 급 격한 증가를 초래하였고, 이로 인하여 야기된 높은 FA 농도 는 반응조 운전 효율을 급격히 악화시키는 요인으로 작용하 였다. 이로 인하여 반응조 내 $\mathrm{pH}$ 는 인위적으로 7.0 으로 조절 되었으며, $\mathrm{pH}$ 조절 4일 이후 부분 아질산화능은 회복되는 것 으로 나타났다.

\section{2. 내부 반송률에 따른 아질산/아탈질 공정 성능 평가}

아탈질/아질산 공정의 성능이 안정화된 period II와 period $\mathrm{IV}$ 구간에서는 내부 반송률을 0 에서 $3.0 \mathrm{Q}$ 으로 조절하였고, 각 구간에서의 운전 성능은 Table1에 요약되었다. 내부 반 송 시스템이 적용되지 않았을 경우에는 호기성 반응조에서 의 부분적인 아탈질 반응이 유도됨에 따라 질소 손실 효율 은 $7.1 \pm 0.6 \%$ 로 나타났다. 내부 반송률이 $3.0 \mathrm{Q}$ 로 증가함에 따라 질소 부하 저감률은 $23.5 \pm 3.9 \%$ 까지 증가하는 것으로 조사되었다. 운전 조건별 저감된 질소 부하는 내부 반송률 이 $0 \mathrm{Q}$ 일 때 $0.1 \pm 0.01 \mathrm{~kg} / \mathrm{m}^{3} / \mathrm{d}, 1.5 \mathrm{Q}$ 일 때 $0.14 \pm 0.02 \mathrm{~kg} / \mathrm{m}^{3} / \mathrm{d}$, $3.0 \mathrm{Q}$ 일 때 $0.22 \pm 0.04 \mathrm{~kg} / \mathrm{m}^{3} / \mathrm{d}$ 로 조사되었다. 또한 $\mathrm{A} / \mathrm{O}$ 유출 아질산염 농도 또한 내부 반송률이 증가함에 따라 감소되는 것으로 나타났다. 이러한 운전 성능을 종합적으로 고려한 결과 아나목스 공정과 연계하기 위한 최적 내부 반송률은 $1.5 \mathrm{Q}$ 로 결정될 수 있었다.

본 연구에서 아탈질/아질산 공정은 아나목스 공정의 안정 성을 향상시키기 위한 전처리 목적으로 적용되었다. 유입수 내 높은 농도의 유기물질 유입 또는 유입수 질소 농도의 변 동 등의 이슈는 현장에서 발생 가능한 변수이므로, 이를 유 동적으로 대처하는 방안은 수립될 필요가 있을 것이다. 본 연구에서는 이를 위하여 아탈질/아질산 공정이 아나목스 공 정을 위한 전처리 개념으로 도입되었고, 내부 반송률에 따 른 유출 아질산염 농도 및 질소 부하 저감 효과 등은 검증 되었다.

\section{3. 유출 알칼리도 및 $\mathrm{pH}$ 에 따른 잔류 질소 농도 영향}

Eq. 2에 나타낸 아나목스 미생물의 화학양론식을 바탕으 로 아나목스 공정의 유입수 내 $\mathrm{NO}_{2} / \mathrm{NH}_{4}$ 비는 1 이상으로 유 지되어야 한다. ${ }^{30)}$

$$
\begin{aligned}
& \mathrm{NH}_{4}^{+}+1.32 \mathrm{NO}_{2}^{-}+0.066 \mathrm{HCO}_{3}^{-}+0.13 \mathrm{H}^{+} \rightarrow \\
& 1.02 \mathrm{~N}_{2}+0.256 \mathrm{NO}_{3}{ }^{-}+0.066 \mathrm{CH}_{2} \mathrm{O}_{0.5} \mathrm{~N}_{0.15}+2.03 \mathrm{H}_{2} \mathrm{O}
\end{aligned}
$$

본 연구에서는 질소 손실률과 더불어 암모니아 산화 효율 을 조절함으로써 아나목스 공정을 위한 적정 $\mathrm{A} / \mathrm{O}$ 유출수 성 상을 결정하고자 하였고, Fig.3에는 유출수 $\mathrm{pH}$ 와 alkalinity 농도에 따른 유출 $\mathrm{NO}_{2} / \mathrm{NH}_{4}$ 비를 나타내었다. 유출 alkalinity 농도가 $330.1 \mathrm{mg} \mathrm{CaCO} / \mathrm{L}$, 유출 $\mathrm{pH}$ 가 6.8 일 때 아나목스 공정을 위한 적정 $\mathrm{A} / \mathrm{O}$ 유출 기질비는 유지되는 것으로 나타 났다.

아질산 공정에서 $\mathrm{AOB}$ 에 의해 $1 \mathrm{~mol}$ 의 $\mathrm{NH}_{4}{ }^{+} \mathrm{N}$ 이 산화될

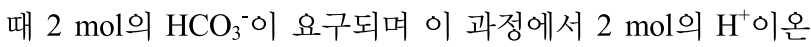
이 생성된다(Eq. 3). 하지만 이에 비하여 NOB에 의해 소비 되는 $\mathrm{HCO}_{3}^{-}$및 생성되는 $\mathrm{H}^{+}$이온이 극히 소량이므로(Eq. 4) 질소 제거 시스템에서의 유출 alkalinity 농도 및 $\mathrm{pH}$ 는 $\mathrm{NH}_{4}{ }^{+} \mathrm{N}$ 의 산화 효율과 직접적인 상관관계가 존재한다. ${ }^{31)}$

$$
\begin{aligned}
& 55 \mathrm{NH}_{4}^{+}+76 \mathrm{O}_{2}+109 \mathrm{HCO}_{3}^{-} \rightarrow \\
& \mathrm{C}_{5} \mathrm{H}_{7} \mathrm{O}_{2}+54 \mathrm{NO}_{2}{ }^{-}+57 \mathrm{H}_{2} \mathrm{O}+104 \mathrm{H}_{2} \mathrm{CO}_{3} \\
& 400 \mathrm{NO}_{2}^{-}+\mathrm{NH}_{4}^{+}+195 \mathrm{O}_{2}+4 \mathrm{H}_{2} \mathrm{CO}_{3} \rightarrow \\
& \mathrm{C}_{5} \mathrm{H}_{7} \mathrm{NO}_{2}+3 \mathrm{H}_{2} \mathrm{O}+5400 \mathrm{NO}_{3}^{-}
\end{aligned}
$$

유출 $\mathrm{pH}$ 와 alkalinity의 상간관계를 이용하여 호기조에 설 치된 산기 장치는 $\mathrm{DO}$ 뿐만 아니라 $\mathrm{pH}$ 에 의한 on/off 시스템 이 적용되었고, 이로 인하여 운전 기간 동안 아나목스 공정 을 위한 적정 $\mathrm{A} / \mathrm{O}$ 유출 성상은 확보될 수 있었다.

일반적인 $\mathrm{A} / \mathrm{O}$ 시스템에서는 유기 탄소원이 충분하다는 조건하에 내부 반송률에 따라 질소 제거 효율은 결정된다. 질산화/탈질화 기반에서는 질소 제거 공정에서는 내부 반송 률 $1 \mathrm{Q}$ 에서도 이론적으로 약 $25 \%$ 의 질소 제거 효율을 달성 

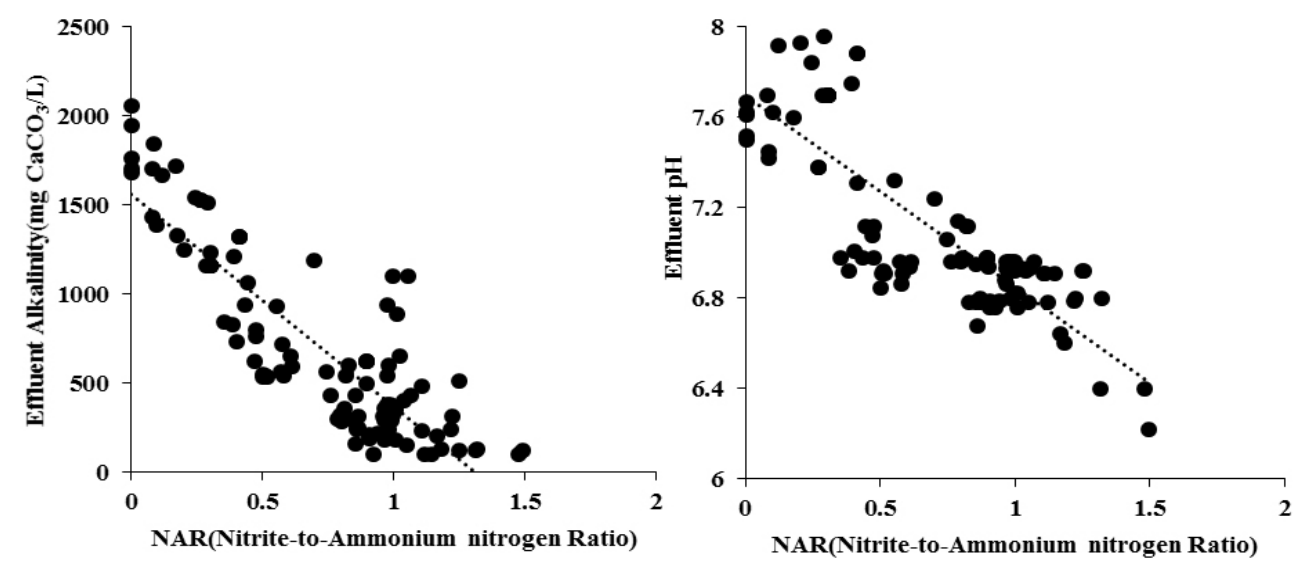

Fig. 3. Effluent nitrite to ammonium ratio according to effluent alkalinity concentration and $\mathrm{pH}$ in denitritation/nitritation reactor.

Table 2. The performance of denitritation/nitritation system according to the internal recycle ratio.

\begin{tabular}{|c|c|c|c|}
\hline & \multicolumn{3}{|c|}{ internal recycle ratio } \\
\hline & Oq & $1.5 q$ & $3 q$ \\
\hline $3^{\text {rd, },}$ Effluent $\mathrm{NH}_{4}{ }^{+}-\mathrm{N}$ concentration $(\mathrm{mg} / \mathrm{L})$ & $69.8 \pm 13.54$ & $24.3 \pm 13.87$ & $154.7 \pm 46.86$ \\
\hline $3^{\text {rd }}$ Effluent $\mathrm{NO}_{2}{ }^{-}-\mathrm{N}$ concentration $(\mathrm{mg} / \mathrm{L})$ & $1.6 \pm 3.06$ & $0.4 \pm 0.70$ & $0.8 \pm 0.27$ \\
\hline Nitrogen Loading Rate (NLR, kg N/m³ day) & $1.42 \pm 0.05$ & $1.41 \pm 0.06$ & $1.45 \pm 0.07$ \\
\hline Nitrogen Removal Rate (NRR, $\mathrm{kg} \mathrm{N} / \mathrm{m}^{3}$ day) & $1.18 \pm 0.04$ & $1.21 \pm 0.06$ & $1.02 \pm 0.10$ \\
\hline T-N removal efficiency (\%) & $81.64 \pm 5.97$ & $88.0 \pm 2.55$ & $75.3 \pm 4.98$ \\
\hline
\end{tabular}

$* 3^{\text {rd: }}$ ANAMMOX reactor

할 수 있지만, 본 연구에서는 $7.1 \%$ 로 낮게 조사되었다. 이 는 유입수 내 낮은 $\mathrm{C} / \mathrm{N}$ 비에 의해 기인된 것으로 이론적으 로 제거 가능한 질소량 대비 낮은 제거 효율을 나타내었다. 하지만 질산염을 탈질하기 위해 요구되는 4 이상의 높은 $\mathrm{C} / \mathrm{N}$ 비 대비 아질산염을 탈질하기 위해서는 유기탄소원이 $40 \%$ 절약될 수 있으므로, 아탈질/아질산 공정에서 0.41 의 낮 은 $\mathrm{C} / \mathrm{N}$ 비에도 불구하고 내부 반송률에 따라 $23.5 \pm 3.9 \%$ 의 질 소 제거 효율은 달성될 수 있었다. 또한 본 연구의 주된 목적 이 질소 부하 저감과 함께 $\mathrm{A} / \mathrm{O}$ 유출수 내 $\mathrm{NO}_{2} / \mathrm{NH}_{4}$ 기질 비 를 충족하는데 있으므로, 추가적인 유기 탄소원 주입 없이 공정은 운영되었고, 최적 운전 조건은 도출될 수 있었다.

\section{4. 아나목스 공정에 의한 질소 제거능 평가}

$\mathrm{A} / \mathrm{O}$ 공정에서의 운전 효율에 따른 아나목스 반응조에서 의 질소 제거 성능은 Table 2에 요약되었다. 식종 미생물로 써 배양된 아나목스 미생물을 사용하여 운전 직후부터 질소 제거 성능이 나타났으며, $\mathrm{A} / \mathrm{O}$ 공정에서의 내부 반송률 $1.5 \mathrm{Q}$ 일 때 아나목스 반응조에서의 질소 제거 효율과 질소 제거 속도는 각각 $88.0 \pm 2.6 \%, 1.21 \pm 0.1 \mathrm{~kg} / \mathrm{m}^{3} / \mathrm{d}$ 를 나타나 질 소 제거능이 가장 높은 것으로 나타났다. 반면, $\mathrm{A} / \mathrm{O}$ 공정에 서의 내부 반송률이 $3 \mathrm{Q}$ 일 때에는 $\mathrm{A} / \mathrm{O}$ 유출수 $\mathrm{NO}_{2} / \mathrm{NH}_{4}$ 비 가 $0.6 \pm 0.04$ 로 조절됨에 따라 질소 제거 효율이 $75.3 \pm 4.9 \%$ 로 급격히 감소되었다.
기존에 개발된 아나목스 공정에서는 반응조 내 유기물 및 아질산염 농도를 조절하기 위한 많은 전략들이 개발되어 왔 다. 대표적으로 SBR 공정을 이용한 유입수 분할 주입 전략 이 고려되며, 이러한 전략의 매카니즘은 아나목스 미생물의 활성을 안정적으로 유지하기 위한 목적으로 적용되었다. 유 사 연구 사례에서는 유기물 전처리를 위한 $\mathrm{SBR}$, 부분 아질 산화를 위한 SBR, 아나목스 SBR로 배열된 질소 제거 시스 템이 $\mathrm{NH}_{4}{ }^{+}-\mathrm{N} 3,000 \mathrm{mg} / \mathrm{L}$ 를 함유하고 있는 매립지 침출수를 처리하기 위하여 적용되었고, 유입수 $\mathrm{COD}$ 는 $3,000 \pm 1,000$ $\mathrm{mg} / \mathrm{L}$ 이었다. ${ }^{32)}$ 본 연구와는 달리 유기물 호기성 조건에서 산화시키기 위한 전처리 공정을 운영하여 아나목스 SBR계 열에서의 유기물 충격 부하를 최소화하였고, 아질산염 저해 를 위한 대안으로 연속 주입 전략이 적용된 변형 SBR 공정 이 적용되었다. 이와 달리 본 연구에서는 유입수 내 유기물 을 호기성 공정에서 제거하는 전략이 아닌 아탈질 반응에 활용함으로써 폭기 에너지 절약과 함께 아나목스 반응조에 서의 아질산염 충격 부하를 저감시키기 위한 전략이 적용되 었다. 그 결과로 아나목스 반응조에 가해지는 질소 부하는 $15.2 \%$ 저감될 수 있었고, $\mathrm{A} / \mathrm{O}$ 유출수 내 아질산염 농도는 $229 \mathrm{mg} / \mathrm{L}$ 에서 $202 \mathrm{mg} / \mathrm{L}$ 까지 감소될 수 있었다.

혐기성 소화 유출수 외에도 매립지 침출수, 음폐수, 돈분 폐수는 고농도 질소를 함유하고 있는 폐수이며 일반적으로 보다 높은 질소 농도뿐만 아니라 높은 유기물 농도를 함유 
하고 있는 폐수이다. 결국 높은 유기물 및 질소 농도에도 아 나목스 미생물의 활성을 안정적으로 유지하기 위한 수단이 요구되며, 3 단 질소 제거 공정은 효과적인 대안으로 적용될 수 있을 것이다. 본 연구에서 도출된 질소 부하 및 아질산염 농도 저감 효과는 유입수 내 유기물질 농도가 높을수록 향 상될 수 있으며, 이는 최종적인 질소 제거 단계인 아나목스 공정에서의 공정 안정성에 크게 기여할 수 있을 것으로 기 대된다.

\section{4. 결 론}

본 연구에서는 실제 혐기성 소화 탈리액을 이용하여 아탈 질/아질산 공정과 결합된 아나목스 공정은 315 일간 운전되 었으며, 내부 반송률을 포함한 주요 운전 인자에 대한 연구 가 수행되었다. 아탈질/아질산 공정에서는 질소 손실 효율 과 유출수 $\mathrm{NO}_{2} / \mathrm{NH}_{4}$ 비가 주요 운전 인자로 고려되었다. 내 부 반송률 $1.5 \mathrm{Q}$ 일 때 $\mathrm{A} / \mathrm{O}$ 시스템에 의한 질소 부하 저감 효 율은 $14.8 \pm 1.4 \%$ 이었으며 $\mathrm{A} / \mathrm{O}$ 유출 $\mathrm{NO}_{2} / \mathrm{NH}_{4}$ 비는 $1.0 \pm 0.1$ 로 나타났다. 이후 아나목스 공정과 연계되었고, 유입 질소 부 하 $1.5 \mathrm{~kg} / \mathrm{m}^{3} / \mathrm{d}$ 일 때 최대 $1.27 \mathrm{~kg} / \mathrm{m}_{3} / \mathrm{d}$ 는 달성되었다.

\section{Acknowledgement}

본 연구는 한국연구재단(NRF-2019R1I1A3A01062509)의 지원으로 수행되었습니다.

\section{References}

1. T.-K. Yoo, Y.-B. Choi, J.-H. Kwon, Evaluation of denitrification efficiency by sulfur denitrification process according to injection type, Journal of the Korea Academia-Industrial Cooperation Society, 17(12), 262-269(2016).

2. M. ten Hoeve, T. Nyord, G. M. Peters, N. J. Hutchings, L. S. Jensen, S. Bruun, A life cycle perspective of slurry acidification strategies under different nitrogen regulations, J. Cleaner Prod., 127, 591-599(2016).

3. D. Choi, J. Kim, B. Youn, J. Jung, Feed distribution based on sensing ammonium concentration after sub-feeding to achieve target effluent nitrogen concentration in sequencing batch reactors, Int. Biodeterior. Biodegrad., 133, 187-193(2018).

4. S. Cao, R. Du, Y. Peng, B. Li, S. Wang, Novel two stage partial denitrification (PD)-anammox process for tertiary nitrogen removal from low carbon/nitrogen $(\mathrm{C} / \mathrm{N})$ municipal sewage, Chem. Eng. J., 362, 107-115(2019).

5. K. Trojanowicz, E. Plaza, J. Trela, Model extension, calibration and validation of partial nitritation - anammox process in moving bed biofilm reactor (MBBR) for reject and mainstream wastewater, Environ. Technol., 40(9), 1079-1100 (2019).

6. B. Wett, R. Rostek, W. Rauch, K. Ingerle, pH-controlled reject-water-treatment, Water Sci. Technol., 37(12), 165-172 (1998).

7. B. Ma, S. Wang, S. Cao, Y. Miao, F. Jia, R. Du, Y. Peng, Biological nitrogen removal from sewage via anammox: recent advances, Bioresour. Technol., 200, 981-990(2016).

8. D. Choi, S. Cho, J. Jung, Key operating parameters affecting nitrogen removal rate in single-stage deammonification, Chemosphere, 207, 357-364(2018).

9. S. M. Kotay, B. L. Mansell, M. Hogsett, H. Pei, R. Goel, Anaerobic ammonia oxidation (anammox) for side-stream treatment of anaerobic digester filtrate process performance and microbiology, Biotechnol. Bioeng., 110(4), 1180-1192 (2013).

10. M. Strous, J. G. Kuenen, J. A. Fuerst, M. Wagner, M. S. N. Jetten, The anammox case - a new experimental manifesto for microbiological eco-physiology, Antonie van Leeuwenhoek, 81, 693-702(2002).

11. D. Choi, D. Lee, W. Yun, J. Jung, Addition of a foaming agent to improve $\mathrm{N}_{2}$ gas permeability of PVA/alginate carriers for deammonification process, Int. J. Hydrogen Energy, 42(45), 27812-27819(2017).

12. W. R. L. Van der Star, W. R. Abma, D. Blommers, J.-W. Mulder, T. Tokutomi, M. Strous, C. Picioreanu, M. C. M. van Loosdrecht, Startup of reactors for anoxic ammonium oxidation: experiences from the first full-scale anammox reactor in Rotterdam, Water Res., 41(18), 4149-4163(2007).

13. D. Choi, K. Cho, J. Jung, Optimization of nitrogen removal performance in a single-stage SBR based on partial nitritation and anammox, Water Res., 162, 105-114(2019).

14. I.-T. Kim, Y.-E. Lee, Y. Jeong, Y.-S. Yoo, A novel method to remove nitrogen from reject water in wastewater treatment plants using a methane-and methanol-dependent bacterial consortium, Water Res., 172, 115512(2020).

15. A. Joss, D. Salzgeber, J. Eugster, R. König, K. Rottermann, S. Burger, P. Fabijan, S. Leumann, J. Mohn, H. Siegrist, Full-scale nitrogen removal from digester liquid with partial nitritation and anammox in one SBR, Environ. Sci. Technol., 43(14), 5301-5306(2009).

16. M. J. Kampschreur, W. R. L. van der Star, H. A. Wielders, J. W. Mulder, M. S. M. Jetten, M. C. M. van Loosdrecht, Dynamics of nitric oxide and nitrous oxide emission during full-scale reject water treatment, Water Res., 42(3), 812-826 (2008).

17. M. J. Kampschreur, R. Poldermans, R. Kleerebezem, W. R. L. van der Star, R. Haarhuis, W. R. Abma, M. S. M. Jetten, M. C. M. van Loosdrecht, Emission of nitrous oxide and nitric oxide from a full-scale single-stage nitritation-anammox reactor, Water Sci. Technol., 60(12), 3211-3217(2009).

18. K. Furukawa, P. K. Lieu, H. Tokitoh, T. Fujii, Development of single-stage nitrogen removal using anammox and partial nitritation (SNAP) and its treatment performances, Water Sci. Technol., 53(6), 83-90(2006).

19. G. Chen, Y. Zhang, X. Wang, F. Chen, L. Lin, Q. Ruan, Y. Wang, F. Wang, W. Cao, P. Chiang, Optimizing of operation strategies of the single-stage partial nitrification-anammox 
process, J. Cleaner Prod., 256, 120667(2020).

20. S. Lackner, E. M. Gilbert, S. E. Vlaeminck, A. Joss, H. Horn, M. C. M. van Loosdrecht, Full-scale partial nitritation/anammox experiences - an application survey, Water Res., 55, 292-303(2014).

21. S. E. Vlaeminck, H. D. Clippeleir, W. Verstraete, Microbial resource management of one-stage partial nitritation/anammox, Microb. Biotechnol., 5(3), 433-448(2012).

22. D. Bolzonella, C. Cavinato, F. Fatone, P. Pavan, F. Cecchi, High rate mesophilic, thermophilic, and temperature phased anaerobic digestion of waste activated sludge: a pilot scale study, Waste Manage., 32(6), 1196-1201(2012).

23. T. Lotti, W. R. L. van der Star, R. Kleerebezem, C. Lubello, M. C. M. van Loosdrecht, The effect of nitrite inhibition on the anammox process, Water Res., 46(8), 2559-2569(2012).

24. Ministry of Environment, Korean water pollution test standard, Notification No. 99-208(2000).

25. Z. Gong, F. Yang, S. Liu, H. Bao, S. Hu, K. Furukawa, Feasibility of a membrane-aerated biofilm reactor to achieve single-stage autotrophic nitrogen removal based on anammox, Chemosphere, 69(5), 776-784(2007).

26. S. Bagchi, R. Biswas, T. Nandy, Alkalinity and dissolved oxygen as controlling parameters for ammonia removal through partial nitritation and anammox in a single-stage bioreactor, J. Ind. Microbiol. Biotechnol., 37, 871-876(2010).

27. A. C. Anthonisen, R. C. Loehr, T. B. S. Prakasam, E. G. Srinath, Inhibition of nitrification by ammonia and nitrous acid, Journal (Water Pollution Control Federation), 48(5), 835-852(1976).

28. H. Sun, Y. Peng, S. Wang, J. Ma, Achieving nitritation at low temperatures using free ammonia inhibition on nitrobacter and real-time control in an SBR treating landfill leachate, J. Environ. Sci., 30, 157-163(2015).
29. S. A. Mousavi, S. Ibrahim, M. K. Aroua, Effect of carbon source on acclimatization of nitrifying bacteria to achieve high-rate partial nitrification of wastewater with high ammonium concentration, Appl. Water Sci., 7, 165-173(2017).

30. A. Mulder, A. A. Van de Graaf, L. A. Robertson, J. G. Kuenen, Anaerobic ammonium oxidation discovered in a denitrifying fluidized bed reactor, FEMS Microbiol. Ecol., 16(3), 177-183(1995).

31. H. Bae, H. Yang, Y.-C. Chung, Y. J. Yoo, S. Lee, High-rate partial nitritation using porous poly (vinyl alcohol) sponge, Bioprocess Biosyst. Eng., 37, 1115-1125(2014).

32. L. Miao, S. Wang, T. Cao, Y. Peng, Optimization of three-stage anammox system removing nitrogen from landfill leachate, Bioresour. Technol., 185, 450-455(2015).

\section{Authors}

\section{Daehee Choi}

Department of Environmental Engineering, Yeungnam University, Postdoctoral Researcher, ORCID (1) 0000-0003-2440-7078

\section{Wonsang Yun}

Samjin Precision Co., Ltd., Assistant Manager, ORCID® 0000-00022150-6693

\section{Dongjin Ju}

Samjin Precision Co., Ltd., Team Manager, ORCiD (이 0000-00029597-083X

\section{Jinyung Jung}

Department of Environmental Engineering, Yeungnam University, Professor, ORCID (1) 0000-0002-2150-6698 